Article

HAGGAG, M.W. ${ }^{1 *}$

ABOU EL ELLA, S.M. ${ }^{2}$

ABOUZIENA H.F. ${ }^{1}$

\section{Phytochemical Analysis, Antifungal, Antimicrobial ACTIVITIES AND APPLICATION OF Eichhornia crassipes Against Some Plant Pathogens}

\section{Análise Fitoquímica, Atividades Antifúngica e Antimicrobiana e Aplicação de Eichhornia crassipes contra Alguns Patógenos de Plantas}

ABSTRACT - Water hyacinth (Eichhornia crassipes) is an oceanic macrophyte and one of the worst sea-going weeds in the world and Egypt. The grouping of substantial metals in water hyacinth was higher in roots than in shoots. Nutrient content e.g. ammonia, nitrate, nitrite and phosphate was higher in the shoots of water hyacinth. Water hyacinth is a wellspring of phytochemicals which have a medicinal function. In this study, the high degree of peroxidation and nonenzymatic antioxidant systems were detected in leaf extracts. The chemical analysis of the leaf extracts was performed using acetone, ethanol, methanol and n-Butyl alcohol. The fractionated extracts showed the presence of some medicine compounds that include phenols, protein, alkaloids, amino acids, carbohydrate, flavonoids, glycosides, tannins, and terpenoids. The fractionated extracts were screened for antimicrobial and antifungal activities. The leaf extracts of E. crassipes exhibited antimicrobial activities against some bacteria: Escherichia coli, Bacillus subtilis, Bacillus cereus, Lactobacillus casei and Pseudomonas aeruginosa, and antifungal activity against six pathogenic fungi i.e. Aspergillus flavus, A. niger, Alternaria alternata, Colletotrichum gloeosporioides, Candida albicans, and Fusarium solani by using the well diffusion method. Streptomycin and Fluconazole were used as a standard as antimicrobial and antifungal agents, respectively. B. subtilis, F. solani, $C$. gloeosporioides and A. alternata were the most susceptible to plant extracts. The most effective antifungal and antimicrobial agent against some plant pathogens was the n-Butyl alcohol extract. Also, it reduced the production of mycotoxin e.g. Aflatoxin B1 and Ochratoxin A. The application of the formulation of the plant extract of E. crassipes protected wheat plants against net blotch diseases. The results indicated that the leaf extractsof E. crassipes have potential as biofungicides and can be used in the industry.

Keywords: antifungal and antimicrobial, biofungicide, Eichhornia crassipes, leaf extracts.

RESUMO - O aguapé (Eichhornia crassipes) é uma macrófita aquática e uma das piores plantas daninhas aquáticas do mundo e do Egito. O agrupamento substancial de metais no aguapé foi maior na raiz do que na parte aérea. Os teores de nutrientes, por exemplo, amônia, nitrato, nitrito e fosfato, foram maiores na parte aérea do aguapé. O aguapé é uma fonte de fitoquímicos que exercem função medicinal. Neste estudo, o alto grau de peroxidação e sistemas antioxidantes não enzimáticos foram detectados nos extratos das folhas. A análise química dos extratos das folhas foi realizada utilizando acetona, etanol, metanol e álcool n-butílico.
Received: February 6, 2016

Approved: June 29, 2016

Planta Daninha 2017; v35:e017159560

1 National Research Centre, Cairo, Egypt; ${ }^{2}$ Channel Maintenance Research Institute, National Water Research Center, Egypt. 
Os extratos fracionados indicaram a presença de alguns compostos de medicamentos que incluem fenóis, proteínas, alcaloides, aminoácidos, hidratos de carbono, flavonoides, glicosídeos, taninos e terpenoides. Foram analisadas as atividades antimicrobiana e antifúngica dos extratos fracionados. Os extratos de folhas de $\boldsymbol{E}$. crassipes apresentaram atividade antimicrobiana contra algumas bactérias: Escherichia coli, Bacillus subtilis, Bacillus cereus, Lactobacillus casei and Pseudomonas aeruginosa e atividade antifúngica contra seis fungos patogênicos, ou seja, Aspergillus flavus, $A$. niger, Alternaria alternata, Colletotrichum gloeosporioides, Candida albicans, e Fusarium solani, utilizando o método de difusão em poços. A estreptomicina e o fluconazol foram utilizados como padrão de agentes antimicrobianos e antifúngicos, respectivamente. B. subtilis, $\boldsymbol{F}$. solani, $\boldsymbol{C}$. gloeosporioides e A. alternata foram os mais suscetiveis aos extratos de plantas. $O$ agente antifúngico e antimicrobiano mais eficaz contra alguns agentes patogênicos de plantas foi o extrato de álcool $n$-butílico. Além disso, ele reduziu a produção de micotoxinas, por exemplo, Aflatoxina B1 e A. A aplicação da formulação dos extratos das plantas de $\boldsymbol{E}$. crassipes protegeu as plantas de trigo contra a mancha reticular. Os resultados indicaram que os extratos das folhas de $\boldsymbol{E}$. crassipes têm potencial como biofungicidas e podem ser utilizados no âmbito industrial.

Palavras-have: antifúngico e antimicrobiano, biofungicida, Eichhornia crassipes, extratos de folhas.

\section{INTRODUCTION}

Eichhornia crassipes (Mart.) Solms., ordinarily known as water hyacinth, is a warm water aquatic plant and the world worst aquatic weed in the world; the plant was recorded in Egypt, India and Australia. It can grow quickly, thereby completely closing water bodies (Ali et al., 2009; Kristie 2012; Chand et al., 2014), and negatively impacting fisheries and related commercial activities. Moreover, it affects the effectiveness of irrigation canals, navigation, transport and hydroelectric programs (Navarro and Phiri, 2000), and increases water flow and flood levels.

Water hyacinth is a source of chemicals with medicinal function (Ahmad, 2007; Jayanthi and Lalitha, 2011; Thamaraiselvi et al., 2012; Joshi and Kaur, 2013). The leaf extract of this plant contains flavonoids, alkaloids, tannins, phenols, which have biological activities such as antiviral, antifungal antitumor and antibacterial agents (Ali et al., 2009; Shanab et al., 2010; Jayanthi and Lalitha, 2011; Aravind et al., 2013). In addition, Water hyacinth has rich oxidative enzymes and nonenzymatic antioxidant systems (Thamaraiselvi et al., 2012). Secondary metabolites, e.g. phenolics and antioxidants, have been considered to be involved in the chemical defense of plants against plant pathogens (Haggag Wafaa et al., 2014, 2015). An alternative approach for detection and development of new and innovative products is increasing the interest of researchers in antimicrobial and antifungal activities of medicinal plants rather than in common weeds which are also the source of several antimicrobial and antifungal compounds (Cushnie, 2005; Alavijeh and Sharma, 2012). There have been studies on the use of plant products as disease control agents, with less toxicity and fewer environmental effects. Thus, the aim of this study to evaluate metal and nutrient accumulation, phytochemical compounds, antifungal and antimicrobial activities of different leaf extracts of E. crassipes against some plant pathogens.

\section{MATERIAL AND METHODS}

\section{Collection of plant material}

Fresh, disease-free leaves of E. crassipes were collected in three locations on the Nile River, El Kanater El Khireia Branch, Cairo, Egypt. The leaves were washed thoroughly twice with running water and once with sterile distilled water; leaf material was then air-dried.

\section{Metal and nutrient accumulation}

The samples of water hyacinths were collected from several drains in El Behiera Governorate, Egypt. Metal accumulated in the plant sample was measured. Heavy metals were analyzed, as 
per standard methods in (Apha, 1985; Hach, 1987), by using an Atomic Absorption Spectrophotometer with acetylene gas as fuel and air as an oxidizer. Operational conditions were adjusted to yield optimal determination. The calibration curves were prepared separately for both metals by running suitable concentration of the standard solutions. Digested samples were aspirated into the fuel-rich air-acetylene flame and the concentrations of the metals were determined from the calibration curves.

Nutrient accumulated in the plant sample was measured. A modification of the Armstrong (1967) procedure was used for the analysis of nitrate plus nitrite. For this analysis, the sample was passed through a cadmium reduction column where nitrate was quantitatively reduced to nitrite. Sulfanilamide was introduced to the sample stream followed by N-(1-naphthyl) ethylenediamine dihydrochloride which couples to form a red azo dye. The stream was then passed through a $10 \mathrm{~mm}$ flow cell and absorbance was measured at $520 \mathrm{~nm}$. The same technique was employed for nitrite analysis, except for the cadmium column that is not present. Nitrate concentration is calculated by subtracting the nitrite value from the combined Nitrate + Nitrite $(\mathrm{N}+\mathrm{N})$ value. Phosphate is analyzed using a modification of the Bernhardt and Wilhelms technique. An acidic solution of ammonium molybdate is added to the sample to produce phosphomolybdic acid and then reduced to phosphomolybdous acid (a blue compound) following the addition of dihydrazine sulfate. The reaction product is heated to $\sim 55 \mathrm{C}$ to enhance color development and then passed through a $10 \mathrm{~mm}$ flow cell and the absorbance measured at $820 \mathrm{~m}$. Ammonium is analyzed via the Berthelot reaction in which hypochlorous acid and phenol react with ammonium in an alkaline solution to form indophenol blue. The sample is passed through a $10 \mathrm{~mm}$ flow cell and measured at $660 \mathrm{~nm}$. This method is a modification of the procedure by Koroleff (1969, 1970).

\section{Antioxidant activity}

The free radical-scavenging activity was measured by 1,1 diphenyl-2-picryl hydrazyl (DPPH) (Nikhat et al., 2009). For this purpose, $1 \mathrm{ml}$ of DDPH solution $(0.1 \mathrm{mM})$ in methanol was added to the extract. Thirty minutes later, absorbance was measured at $517 \mathrm{~nm}$ using a UV-Visible spectrophotometer (Shimadzu UV - 1650PC). A control was prepared without adding extract. Ascorbic acid at various concentrations $\left(2-20 \mu \mathrm{g} \mathrm{mL}^{-1}\right)$ was used as a standard. The percentage of DPPH-scavenging activity was calculated as DPPH Scavenged (\%) = A control - A test $/$ A control $\mathrm{X} 100$, where A control represents absorbance of control reaction and A test represents absorbance in presence of the extract. Ascorbic acid was used as a standard.

\section{Peroxidase}

Peroxidation of mitochondrial samples was estimated as malonaldehyde (MDA) equivalents by keeping the samples in boiling water bath with $1 \mathrm{~mL}$ thiobarbituric acid (TBA) reagent for $15 \mathrm{~min}$. After cooling, absorbance was measured at $532 \mathrm{~nm}$ using an UV Visible Spectrophotometer (Shimadzu UV-1650PC). A control was run simultaneously without addition of extract. Butylated Hydroxyl Toluene (BHT) was included as a standard. Peroxidation inhibitory activity was calculated as, Inhibition $(\%)=$ Control - Test $/$ Control X 100.

\section{Solvent extraction}

Acetone, ethanol, methanol and n-Butyl alcohol extracts of E. crassipes leaves were prepared according to (India, 1966). These extracts were concentrated to dryness in a flash evaporator under reduced pressure and controlled temperature $\left(40-50{ }^{\circ} \mathrm{C}\right)$, and they were stored in a refrigerator.

\section{Phytochemical analysis}

Phytochemical screening of the leaf extracts of E. crassipes was carried out as per the standard procedure (Harborne, 2005). 


\section{Total carbohydrate estimation}

The phenol sulphuric acid method described by Dubois et al. (1956) was followed for estimation of total carbohydrates. The absorbance was recorded at $620 \mathrm{~nm}$ using a UV Spectrophotometer. The quantity of sugar was expressed as $\mathrm{mg} \mathrm{g}^{-1}$ fresh weight of tissue.

\section{Protein estimation}

The Kjeldahl Nitrogen method was used for protein estimation in the plant material; in this method, ammoniacal nitrogen is oxidized by sulfuric acid in the presence of a catalyst to $\left(\mathrm{NH}_{4}\right)$ $\mathrm{SO}_{4}$.

\section{Test for alkaloids}

A fraction of the extract was treated with Wagner's test reagent [1.27 g of iodine and $2 \mathrm{~g}$ of potassium iodide in $100 \mathrm{~mL}$ of water] and observed for the formation of a reddish brown precipitate.

\section{Test for flavonoids}

A small amount of extract was treated with aqueous $\mathrm{NaOH}$ and $\mathrm{HCl}$ and observed for the formation of a yellow orange color.

\section{Test for tannins using Braymer's test}

$100 \mathrm{~mL}$ of extract were treated with $10 \%$ alcoholic ferric chloride solution and observed for formation of a blue or greenish solution.

\section{Test for rerpenoids using liebermann-Burchard test}

The extract $(1 \mathrm{~mL})$ was treated with chloroform, acetic anhydride and drops of $\mathrm{H}_{2} \mathrm{SO}_{4}$ were added. The extract was observed for the formation of a dark green color.

Test for Phenols using the Ferric chloride test: The fraction of thr extract was treated with $5 \%$ ferric chloride and observed for formation of a deep blue or black color.

\section{Screening of antifungal and antimicrobial activities}

\section{Minimum inhibitory concentration (MIC) measurements}

A current definition of the minimum inhibitory concentration (MIC) is the lowest concentration which resulted in maintenance or reduction of inoculums viability (Carson et al., 1995). The serial tube dilution technique was used to determine the MIC value of the ethanol, acetone, methanol, n-Butyl alcohol and distilled water extracts of E. crassipes against bacteria and fungi. The extract $(0.512 \mathrm{mg})$ was dissolved in $2 \mathrm{~mL}$ distilled water ( 2 tween- 80 drops were added to facilitate dissolution) to obtain the stock solution. After preparation of suspensions of test organisms $\left(10^{7}\right.$ organism per $\left.\mathrm{mL}\right), 1$ drop of suspension $(0.02 \mathrm{~mL})$ was added to each broth dilution. After $18 \mathrm{~h}$ incubation at $37^{\circ} \mathrm{C}$, the tubes were then examined for growth. The MIC of the extract was taken as the lowest concentration that showed no growth. Growth was observed in those tubes where the concentration of the extract was below the inhibitory level and the broth medium was observed to be turbid. Distilled water with 2 drops of tween-80 and kanamycin were used as negative and positive controls, respectively.

\section{Selection of microorganisms}

The bacteria included in the present study were Escherichia coli, Bacillus subtilis, Bacillus cereus, Lactobacillus casei and Pseudomonas aeruginosa procured from and six pathogenic fungal 
strains such as, Aspergillus flavus, A. niger, Alternaria alternata, Colletotrichum gloeosporioides, Candida albicans, and Fusarium solani were selected for the present investigation. The pathogenic bacteria and fungi were originally obtained from the Plant Pathology Dept., National Research Centre and used for the present investigation. Bacteria were pre-cultured in nutrient broth overnight in a rotary shaker at $35^{\circ} \mathrm{C}$, centrifuged at $10,000 \mathrm{rpm}$ for $6 \mathrm{~min}$; the pellet was suspended in double distilled water and cell density was standardized spectrophotometrically (A595 $\mathrm{nm}$ ) for approximately $10^{8}$ spores $\mathrm{mL}^{-1}$. The fungal inoculums were prepared from 6 to 10 day old cultures grown in Potato dextrose agar medium. Petri dishes were flooded with 9 to $11 \mathrm{~mL}$ of distilled water and the conidia were scraped using sterile spatula. The spore density of each fungus was adjusted with a spectrophotometer (A595 $\mathrm{nm}$ ) to obtain a final concentration of approximately $10^{5}$ spores $\mathrm{mL}^{-1}$.

\section{Antimicrobial and antifungal activities}

The antifungal and antimicrobial activities of ethanol, acetone, methanol, n-Butyl alcohol and distilled water extracts of $E$. crassipes were tested against the selected bacterial and fungal strains using a concentration of $20 \mathrm{mg} \mathrm{m}^{-1}$. The sterilized nutrient agar and potato dextrose agar medium was poured into each sterile petriplates and allowed to solidify. By using sterile cotton swabs, fresh bacterial and fungal cultures were spread over the plates by following the spread plate technique. One $5 \mathrm{~mm}$ wells were made into the agar plates with the help of a sterile cork borer. The wells were loaded with $200 \mu \mathrm{L}$ of ethanol, acetone, methanol, n-Butyl alcohol and distilled water extracts of E. crassipes were loaded into separated wells. The plates were incubated for 48 hours at $35^{\circ} \mathrm{C}$ for bacteria and $26^{\circ} \mathrm{C}$ for $48-72$ hours for fungi. The antibiotic sensitivity test was investigated using standard antibiotics Streptomycin (10 $\mu \mathrm{g}$ per disc) for bacteria and Fluconazole (10 $\mu \mathrm{g}$ per disc) for fungi. Each experiment was repeated five times and the mean of the diameter of the inhibition zones was calculated around the wall in $\mathrm{mm}$.

\section{Effect of plant extract on growth and aflatoxin production of toxigenic fungi}

One $\mathrm{mL}$ of conidial suspension of fungi $\left(1 \mathrm{xl}^{7}\right.$ conidia $\left.\mathrm{mL}^{-1}\right)$ was inoculated into $100 \mathrm{~mL}$ of sterilized medium with $10 \mu \mathrm{g}$ of the best solvent extract in a glass bottle volume $250 \mathrm{~mL}$. They were then incubated at room temperature for 10 days. Three replications were used for each treatment (including the control). Observations were made on the dry weight of mycelia of fungi and aflatoxin production. The dry weight of mycelia was determined by drying the fungal colonies in an oven at $70{ }^{\circ} \mathrm{C}$ for 4 days to constant weight. Aflatoxin B1 content was determined using a High Performance Liquid Chromatography method (Christian, 1990). Bottles were capped and shaked on a rotary shaker at $120 \mathrm{rpm}$ for $90 \mathrm{~min}$ and the suspensions were centrifuged at $3,500 \mathrm{rpm}$ for $20 \mathrm{~min}$. The supernatants were transferred to glass bottles and kept at room temperature for hours. Aflatoxin levels were measured using high performance liquid chromatography (HPLC) (model: Perkin Elmer series 200 UV/VIS) with a C18 column that had an internal diameter of $300 \times 3.9 \mathrm{~mm}$. The HPLC apparatus was equipped with a UV detector, and fluorescence was measured using $365 \mathrm{~nm}$ excitation and $430 \mathrm{~nm}$ emission wavelengths. The mobile phase consisted of methanol: acetic acid: water $(20: 20: 60 \mathrm{v} / \mathrm{v} / \mathrm{v})$. Total run time for

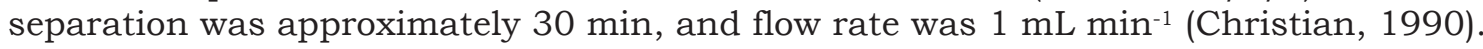

\section{Product formulation}

The formulation was prepared using $10 \% \mathrm{n}$-butanol extracts of leaves. $0.1 \%$ of oil formulation and Wilt-Pruf were used as a soluble sticker for the formulation. CMC was also prepared as a control.

\section{Field experiment}

Two field experiments were designed in a randomized complete block design with three replications in two fields of wheat (Giza $160 \mathrm{cv}$.) plants grown in Noubaria, Beheira Governorate under natural infection conditions. Two foliar sprays of formulation were prepared after the 
seeds had been sown for two and three months. Sterile distilled water was used as a control. Net blotch disease development was measured during growth periods. Growth parameters and yield/ plant at harvest time, grain and yields were estimated on a plot basis.

\section{Statistical analyses}

The effects of the treatments on disease severity were analyzed by using Duncan Multiple Range Test (SPSS software 16).

\section{RESULTS AND DISCUSSION}

\section{Heavy metal accumulation in water hyacinth}

Table 1 shows the average values of common heavy elemental contents such as Aluminum, Barium, Cadmium, Chromium, Cobalt, Copper, Iron, Lead, Manganese, Nickel and Zinc in water hyacinth tissues. Data of Table 1 indicate that the concentration of various heavy metals in all water hyacinths was higher in roots than in shoots (Cmri, 2015).

Table 2 shows the means of nutrient contents in in water hyacinth tissues values. Data indicated that the concentration of various nutrients e.g. Ammonia, Nitrate, Nitrite and Phosphate in shoots of water hyacinth was higher. Nitrate was the most abundant nutrient in shoots. According to Wallace and Romney (1977), the distribution of trace elements in plants can be categorized into three groups: (1) somewhat uniformly distributed between roots and shoots, e.g. Cd, $\mathrm{Cu}, \mathrm{Pb}, \mathrm{Ni}, \mathrm{Cr}$ and $\mathrm{Zn}$; (2) usually more in roots than in shoots with moderate to sometimes large quantities in shoots, e.g., $\mathrm{Al}, \mathrm{Ba}, \mathrm{Fe}$, and $\mathrm{Mn}$; and (3) mostly in roots with a very small amount in shoots e.g. Co.

In general, most studies reported higher concentration of metals in roots than in shoots. Heavy metal concentrations were reported to

Table 1 - Heavy metal content of water hyacinth tissues (general means from several water hyacinths)

\begin{tabular}{|l|c|c|}
\hline \multirow{2}{*}{ Element $\left(\mathrm{mg} \mathrm{kg}^{-1}\right)$} & \multicolumn{2}{|c|}{ Plant part } \\
\cline { 2 - 3 } & Shoots & Roots \\
\hline Aluminum $(\mathrm{Al})$ & $305.4-521.0$ & $2656.0-7518.0$ \\
\hline Barium $(\mathrm{Ba})$ & $28.8-39.6$ & $42.0-92.6$ \\
\hline Cadmium $(\mathrm{Cd})$ & $<0.001$ & $<0.001$ \\
\hline Chromium $(\mathrm{Cr})$ & $2.1-16.2$ & $9.8-28.8$ \\
\hline Cobalt $(\mathrm{Co})$ & $<0.003$ & $1.8-6.6$ \\
\hline Copper $(\mathrm{Cu})$ & $51.6-191.8$ & $62.2-244.2$ \\
\hline Iron $(\mathrm{Fe})$ & $247-402.0$ & $2370-6402$ \\
\hline Lead $(\mathrm{Pb})$ & $<0.003$ & $<0.003$ \\
\hline Manganese $(\mathrm{Mn})$ & $341.8-471.8$ & $496.8-2226$ \\
\hline Nickel $(\mathrm{Ni})$ & $8.6-13.8$ & $10.6-26.4$ \\
\hline Zinc $(\mathrm{Zn})$ & $18.6-39.2$ & $20.8-56.8$ \\
\hline
\end{tabular}
be higher in roots in most studies (Cataldo et al., 1981; Rauser, 1987). Normally, Zn, Cd or Ni concentrations are 10 (or more) times higher in roots than those in shoots (Chaney et al., 1997). The present result agrees with Soltan and Rashed (2003), who reported that they treated water hyacinth with several heavy metals $(\mathrm{Cd}, \mathrm{Co}, \mathrm{Cr}, \mathrm{Cu}, \mathrm{Mn}, \mathrm{Ni}, \mathrm{Pb}$ and $\mathrm{Zn}$ ) and concluded that water hyacinth accumulated higher concentrations of heavy metals in the roots than that in the shoots. Thus, leaf was used for future studies.

Table 2 - Nutrient content of water hyacinth tissues (general means from several water hyacinths)

\begin{tabular}{|l|c|c|c|}
\hline \multirow{2}{*}{$\begin{array}{c}\text { Chemical parameters } \\
\left(\mathrm{mg} \mathrm{kg}^{-1}\right)\end{array}$} & \multicolumn{3}{|c|}{ Location No. } \\
\cline { 2 - 4 } & 1 & 2 & 3 \\
\hline Ammonia $\left(\mathrm{NH}_{4}\right)$ & 0.651 & 0.616 & 0.572 \\
\hline Nitrate $\left(\mathrm{NO}_{3}\right)$ & 18.0 & 16.8 & 16.8 \\
\hline Nitrite $\left(\mathrm{NO}_{2}\right)$ & 0.26 & 0.20 & 0.13 \\
\hline Phosphate $\left(\mathrm{PO}_{4}\right)$ & 0.58 & 0.52 & 0.36 \\
\hline
\end{tabular}

\section{Phytochemical analysis}

The levels of both peroxidase and antioxidant enzymes activities in leaf plant are shown in Table 3. Peroxidase and antioxidant activity levels were recorded by (0.82 units/ $\mathrm{mg}$ protein) and (0.020 units/mg protein), respectively. Data in Table 4 show that chemical analysis of the leaf extracts using acetone, distilled water, ethanol, methanol and 
Table 3 - Enzymatic antioxidants in Eichhornia crassipes leaves

\begin{tabular}{|c|c|c|c|c|c|}
\hline \multirow{3}{*}{ Eichhornia crassipes } & \multicolumn{2}{|c|}{$\begin{array}{l}\text { Peroxidase } \\
\end{array}$} & \multicolumn{3}{|c|}{ Ascorbic antioxidant } \\
\hline & Unit $\mathrm{mg}^{-1}$ protein & Unit $\mathrm{g}^{-1}$ tissue & Unit $\mathrm{mg}^{-1}$ protein & Unit $\mathrm{g}^{-1}$ tissue & $\mathrm{IC} 50\left(\mu \mathrm{g} \mathrm{mL}^{-1}\right)$ \\
\hline & 0.82 & 3.56 & 0.020 & 0.046 & 11.8 \\
\hline
\end{tabular}

Table 4 - Phytochemical analysis of leaf extracts of Eichhornia crassipes

\begin{tabular}{|l|c|c|c|c|c|}
\hline \multicolumn{1}{|c|}{ Phytocompounds } & Distilled water & Acetone & Ethanol & Methanol & n-Butyl \\
\hline Alkaloids & + & + & - & + & + \\
\hline Flavonoids & - & - & - & + & + \\
\hline Phenols & - & - & + & - & + \\
\hline Carbohydrates & + & - & + & - & - \\
\hline Protein & - & - & + & - & + \\
\hline Amino acids & - & - & - & + & - \\
\hline Tannins & - & + & + & + & + \\
\hline Terpenoids & + & + & + & + \\
\hline
\end{tabular}

n-Butyl alcohol extracts indicated the presence of medicinal compounds such as alkaloids, amino acids, carbohydrate, flavonoids, phenols, protein, tannins and terpenoids. n-Butyl is the best effective solvent to extract most phytochemical compounds. These results of phytochemical screening were found in other studies (Ahmad, 2007, Jayanthi and Lalitha, 2011; Thamaraiselvi et al., 2012; Joshi and Kaur, 2013).

\section{Antibacterial and antifungal assay}

Minimum inhibitory concentration (MIC) measurement: The impact of each solvent extract against the selected tested bacteria and fungi was assessed as Minimum Inhibitory Concentration (MIC) values of the extracts i.e distilled water, acetone, ethanol, methanol and n-Butyl alcohol, as shown in Tables 5 and 6 . The MIC values against the tested bacteria ranged from 18 to $35 \mu \mathrm{g} \mathrm{mL}^{-1}$ and for the tested pathogenic fungi, from 20 to $63 \mu \mathrm{g} \mathrm{m}^{1}$ (Table 6). The MIC assay indicated that Eichhornia crassipes extracts have antibacterial and antifungal activities against all tested bacteria and fungi at lower concentration. N-butanol and methanol have the most effective antimicrobial and antifungal activities against $B$. subtilis, $F$. solani and C. gloeosporioides compared with antibiotics Streptomycin and Fluconazole at the recommended dose.

The antibacterial and antifungal activities of extracts, fractionated compound of Eichhornia crassipes activities against Escherichia coli, Bacillus subtilis, Bacillus cereus, Lactobacillus casei and Pseudomonas aeruginosa, Aspergillus flavus, A. niger, Alternaria alternata, Colletotrichum gloeosporioides, Candida albicans, and Fusarium solani were carried out by the well diffusion method. In this study, distilled water, acetone, ethanol, methanol and n-Butyl alcohol extracts of E. crassipes, compared with antibiotics streptomycin and fluconazole, exhibited potential as antimicrobial and antifungal agents (Tables 5 and 7). A clear zone of growth inhibition was found around the wall because of diffusion of compounds. The diameter of the inhibition zone differed according to the relative susceptibility of the test microorganisms to a particular antimicrobial agent. In general, all leave extracts exhibited broad spectrum of both antimicrobial and antifungal activities compared with antibiotics. B. subtilis, F. solani and C. gloeosporioides were the most susceptible to all solvent extracts. Data in Table (7) indicated that the maximum antibacterial activity was found by the n-Butyl alcohol extract against all tested bacteria. The acetone extract showed minimum effects against all bacteria. Similar data (Table 8) showed that the maximum antifungal activity was found by the n-Butyl alcohol extract against all tested fungi. The acetone extract showed minimum effects against all fungi. 
HAGGAG, M.W., ABOU EL ELLA, S.M. and ABOUZIENA, H.F. Phytochemical analysis, antifungal, antimicrobial activities and ...

Table 5- Minimum inhibitory concentration (MIC) of Eichhornia crassipes

\begin{tabular}{|c|c|c|c|c|c|c|}
\hline \multirow[b]{2}{*}{ Fungi } & \multicolumn{6}{|c|}{ MIC value $\mu \mathrm{g} \mathrm{mL}^{-1}$} \\
\hline & $\begin{array}{c}\text { Distilled } \\
\text { water }\end{array}$ & Acetone & Ethanol & Methanol & $\begin{array}{l}\text { n-Butyl } \\
\text { alcohol }\end{array}$ & $\begin{array}{c}\text { Control } \\
\text { fluconazole }\end{array}$ \\
\hline Aspergillus flavus & 64 & 32 & 16 & 16 & 16 & 8 \\
\hline Aspergillus niger & 64 & 32 & 16 & 16 & 16 & 8 \\
\hline Alternaria alternata & 64 & 32 & 16 & 16 & 8 & 16 \\
\hline Colletotrichum gloeosporioides & 64 & 32 & 32 & 16 & 8 & 16 \\
\hline Fusarium solani & 64 & 32 & 32 & 16 & 8 & 16 \\
\hline Candida albicans & 64 & 64 & 64 & 64 & 32 & 8 \\
\hline
\end{tabular}

Table 6 - Minimum inhibitory concentration (MIC) of Eichhornia crassipes leaf extracts against some fungal pathogens

\begin{tabular}{|l|c|c|c|c|c|c|}
\hline \multirow{2}{*}{\multicolumn{1}{|c|}{ Bacteria }} & \multicolumn{6}{c|}{ MIC value $\left(\mu \mathrm{g} \mathrm{mL}^{-1}\right)$} \\
\cline { 2 - 8 } & $\begin{array}{c}\text { Distilled } \\
\text { water }\end{array}$ & Acetone & Ethanol & Methanol & $\begin{array}{c}\text { n-Butyl } \\
\text { alcohol }\end{array}$ & $\begin{array}{c}\text { Control } \\
\text { streptomycin }\end{array}$ \\
\hline Escherichia coli & 64 & 16 & 16 & 16 & 16 & 2 \\
\hline Bacillus subtilis & 64 & 16 & 16 & 16 & 16 & 2 \\
\hline Bacillus cereus & 64 & 32 & 32 & 16 & 16 & 4 \\
\hline Lactobacillus casei & 64 & 32 & 32 & 32 & 16 & 8 \\
\hline Pseudomonas aeruginosa & 64 & 64 & 64 & 32 & 32 & 8 \\
\hline
\end{tabular}

Table 7 - Antibacterial activity of Eichhornia crassipes against pathogenic bacteria

\begin{tabular}{|c|c|c|c|c|c|c|}
\hline \multirow[b]{2}{*}{ Bacteria } & \multicolumn{6}{|c|}{ Zone of inhibition (diameter in $\mathrm{mm}$ ) } \\
\hline & $\begin{array}{c}\text { Distilled } \\
\text { water }\end{array}$ & Acetone & Ethanol & Methanol & $\begin{array}{l}\text { n-Butyl } \\
\text { alcohol }\end{array}$ & $\begin{array}{c}\text { Control } \\
\text { streptomycin }\end{array}$ \\
\hline Escherichia coli & 6.4 & 8.3 & 8.2 & 11.3 & 22.4 & 18.6 \\
\hline Bacillus subtilis & 7.6 & 10.4 & 10.3 & 12.4 & 23.8 & 25.3 \\
\hline Bacillus cereus & 3.3 & 7.6 & 9.6 & 10.7 & 17.7 & 20.3 \\
\hline Lactobacillus casei & 5.7 & 9.3 & 3.5 & 6.5 & 11.3 & 20.6 \\
\hline Pseudomonas aeruginosa & 5.3 & 8.6 & 4.4 & 9.3 & 15.3 & Nile \\
\hline LSD & 0.3 & 0.6 & 0.7 & 0.7 & 1.7 & 0.8 \\
\hline
\end{tabular}

Table 8 - Antifungal activity of Eichhornia crassipes against pathogenic fungi

\begin{tabular}{|l|c|c|c|c|c|c|}
\hline \multirow{2}{*}{\multicolumn{1}{c|}{ Fungi }} & \multicolumn{6}{c|}{ Zone of inhibition (diameter in mm) } \\
\cline { 2 - 7 } & $\begin{array}{c}\text { Distilled } \\
\text { water }\end{array}$ & Acetone & Ethanol & Methanol & $\begin{array}{c}\text { n-Butyl } \\
\text { alcohol }\end{array}$ & $\begin{array}{c}\text { Control } \\
\text { fluconazole }\end{array}$ \\
\hline Aspergillus flavus & 3.4 & 9.3 & 9.5 & 13.3 & 22.4 & 18.7 \\
\hline Aspergillus niger & 3.6 & 10.4 & 11.3 & 15.4 & 23.8 & 19.8 \\
\hline Alternaria alternata & 4.5 & 10.7 & 10.8 & 14.5 & 23.7 & 19.4 \\
\hline Colletotrichum gloeosporioides & 4.1 & 8.8 & 13.7 & 15.3 & 24.6 & 18.7 \\
\hline Fusarium solani & 4.7 & 8.5 & 13.4 & 18.3 & 25.3 & 20.4 \\
\hline Candida albicans & 3.5 & 9.6 & 8.5 & 9.7 & 21.5 & 22.4 \\
\hline LSD & 0.2 & 0.7 & 0.7 & 0.7 & 1.1 & 0.9 \\
\hline
\end{tabular}


Water extracts of Eichhornia crassipes showed good activity against all the bacteria and fungi tested. These results of antimicrobial activity of different extracts of E. crassipes were similar to the results found by others authors (Jayanthi and Lalitha, 2011, Thamaraiselvi et al., 2012; Joshi and Kaur, 2013; Chand et al., 2014).

Water hyacinth, which is often considered as a weed, has been recently studied by many researchers for its phytochemical and pharmaceutical applications. Based on the present study, it can be concluded that the leaf extracts of water hyacinth showed significant antimicrobial and antifungal activities against all the microorganisms tested. The extracts and compounds Eichhornia crassipes are of new interest as antifungal and antimicrobial agents against some plant pathogens. Eichhornia crassipes was found to be rich in crude protein and antifungal compounds.

\section{Impact of plant extract on dry weight and aflatoxin production of toxigenic fungi}

Significant inhibition of both Aspergllii growth was also observed in n-butanol extract of Eichhornia crassipes (Table 9). The same results were additionally recorded for mycotoxin production. High reduction of Aflatoxin B1 and Ochratoxin A was recorded in contrast with the control (water).

Table 9 - Effect of plant extract on dry weight and aflatoxin production of toxigenic fungi

\begin{tabular}{|l|c|c|c|c|c|c|}
\hline \multirow{2}{*}{$\begin{array}{c}\text { n-butanol extract } \\
\text { Eichhornia crassipes }\end{array}$} & \multicolumn{2}{|c|}{$\begin{array}{c}\text { Mycelium growth } \\
\left(\mathrm{mg} \mathrm{L}^{-1}\right)\end{array}$} & \multicolumn{4}{c|}{ Mycotoxin production $\left(\mu \mathrm{g} \mathrm{L}^{-1}\right)$} \\
\cline { 2 - 7 } & Water & \multirow{2}{*}{$\mathrm{n}$-butanol } & \multicolumn{2}{|c|}{ Water } & \multicolumn{2}{c|}{ n-butanol } \\
\cline { 4 - 7 } & & & Aflatoxin B1 & Ochratoxin A & Aflatoxin B1 & Ochratoxin A \\
\hline Aspergillus flavus & 31.8 & 1.40 & 3.5 & ND & 0.77 & ND \\
\hline Aspergillus niger & 28.8 & 0.87 & ND & 2.5 & ND & 0.6 \\
\hline Alternaria alternata & 31.2 & 0.70 & ND & ND & ND & ND \\
\hline Colletotrichum gloeosporioides & 35.6 & 0.76 & ND & ND & ND & ND \\
\hline Fusarium solani & 31.3 & 0.65 & ND & ND & ND & ND \\
\hline Candida albicans & ND & ND & ND & ND & ND & ND \\
\hline
\end{tabular}

\section{Field experiment}

The impact of formulation of E. crassipes in controlling wheat leaf spots was carried out in two field tests (Table 10). The data revealed that there was a highly significant difference between plants sprayed with E. crassipes extract, fungicide and untreated control. The foliar spray of the extract significantly decreased the incidence of net blotch disease in two field stations compared with with the untreated control, and it increased grain yield (Table 10).

Table 10 - Incidence of net blotch disease (\%) of wheat plants sprayed with the formulation of Eichhornia crassipes extract in two locations

This study demonstrated that E. crassipes has a potential for uptake of organic material and it is additionally used as biofungicidal agent. This study proposes that the Eichhornia crassipes plant can be beneficially used as biofungicide. Water hyacinth is rich in oxidative enzymes (Thamaraiselvi et al., 2012) and is also a source of many antimicrobial and antifungal compounds (Alavijeh and Sharma, 2012).

\begin{tabular}{|c|c|c|}
\hline Exp. & Treatment & $\begin{array}{l}\text { Net blotch } \\
\text { of wheat }\end{array}$ \\
\hline \multirow{3}{*}{ Location. I } & Control & 43.70 \\
\hline & Fungicide & 8.80 \\
\hline & Formulation of E. crassipes & 3.54 \\
\hline \multirow{3}{*}{ Location. II } & Control & 47.70 \\
\hline & Fungicide & 9.60 \\
\hline & Formulation of E.crassipes & 4.65 \\
\hline LSD & & 2.43 \\
\hline
\end{tabular}




\section{REFERENCES}

Ahmad S. Introduction of the plant constituents and their tests. New Delhi: Department of Pharmacognosy and Phytochemistry, 2007. p. $2-40$

Alavijeh K.P., Sharma D. A study of antimicrobial activity of few medicinal herbs. Asian J Plant Sci Res. 2012;2:496-502.

Ali H. et al. The world's worst aquatic plant as a safe cancer medicine "Antitumor activity on melanoma induced mouse by Eichhornia crassipes: in vivo studies. J Pharm Res. 2009;2:1365-6.

American Public Health Association - APHA. Standard methods for the examination of water and waste water. $10^{\text {th }}$ ed. Washington D.C: American Public Health Association, 1985. p.391-448.

Aravind R.K. et al. Detailed analysis on phytochemicals, antioxidants, antimicrobial activity of Eichhornia crassipes. Inter J Sci Res. 2013;2:17-9.

Armstrong F.A.J., Stearns C.R., Strickland J.D.H. The measurement of upwelling and subsequent biological processes by means of the Technlcont" Autoxnelyzer" and associated equipment. Deep-Sea Res. 1967;14:381-9.

Carson C.F., Hammer K.A., Riley T.V. Broth micro-dilution method for determination of susceptibility of Escherichia coli and Staphylococcus aureus to the essential oil of Malaleuca alterifolia (Tea tree oil). Microbios. 1995;82:181-5.

Cataldo C.A., Garland T.R., Wildung R.E. Cadmium distribution and chemical fate in soya bean plants. Plant Physiol. 1981;68:835-9.

Chand L., Moolchand M., Singh R.P. Phytochemical study of Eichhornia crassipes in Sri Ganganagar District of Rajasthan, India. J Pharm Phytochem. 2014;3:176-7.

Chaney R.L. et al. Phytoremediation of soil metals. Curr Opinion Biotechnol. 1997;8:279-84.

Channel Maintenance Research Institute - CMRI. "Improve the water quality in drains by using water plant. 2015. (Technical Report)

Christian G. HPLC Tips and Tricks. Oxford: Great Britian at the Iden Press; 1990. 608p.

Cushnie T., Lamb A.J. Antimicrobial activity of flavonoids. Inter J Antimicrob Agents. 2005;26:343.

Dubois M. et al. Colorimetric method for determination of sugar and related substances. Analytic Chem. 1956;28:350-6.

Hach Company. Procedures for water and waste water analysis. $2^{\text {nd }} . e d$. Loveland: 1987.

Haggag M.W. et al. Enhancement of wheat resistant to diseases by elicitors. Res J Pharm Biol Chem Sci. 2014;3:1530.

Haggag M.W. et al. Phenolic and antioxidants enzymes accumulation in sugar beet cultivars in response to inoculation with plant growth promoting Rhizobacteria. Wulfenia J. 2015;22:235-42.

Harborne J.B. Phytochemical methods a guide to modern techniques of plant analysis. $2^{\text {nd }}$. ed. London: Chapman \& Hall, 2005 .

India. Ministry of Health and Family. Pharmacopoeia of India. New Delhi: Controller of Publication, 1966. v.4

Jayanthi P., Lalitha P. Determination of the in vitro reducing power of the aqueous extract of Eichhornia crassipes (Mart.) Solms. J Pharm Res. 2011;4:4003-5.

Joshi M., Kaur S. In vitro evaluation of antimicrobial activity and phytochemical analysis of Calotropis procera, Eichhornia crassipes and Datura innoxia leaves. Asian J Pharm Clinical Res. 2013;6:25-8.

Koroleff F. Direct determination of ammonia in natural waters as Indophenol Blue. International Conference on Evolvable Systems, ICES, 1969.

Koroleff F. The above paper revised. International Conference Exploration Sea; Information on techniques and methods for sea water analysis. 1970. p.19-22. (Interlab Report, 3) 
Kristie T. Plants, garden plants by name water hyacinth. Available at: 2016. http://www.ehow.com/facts.

Navarro L., Phiri G. Water Hyacinth in Africa and the Middle East. A survey of problems and solutions. Ottawa: International Development Research Centre, 2000.

Nikhat F., Satynarayana D., Subhramanyam E.V.S. Isolation characterization and screening of antioxidant activity of the roots of Syzygiumcuminii (L) Skeel. Asian J Res Chem. 2009;2:218-21.

Rauser W.E. Compartmental efflux analysis and removal of extracellular cadmium from roots. Plant Physiol. 1987;85:62-5.

Shanab S.M. et al. Allelopathic Effects of water hyacinth (Eichhornia crassipes). PlusOne. 2010;5:1-8.

Soltan M.E., Rashed M.N. Laboratory study on the survival of water hyacinth under several conditions of heavy metal concentrations. Adv Environ Res. 2003;7:321-34.

Thamaraiselvi P., Lalitha P., Jayanthi P. Preliminary studies on phytochemicals and antimicrobial activity of solvent extracts of Eichhornia crassipes (Mart.) Solms. Asian J. Plant Sci Res. 2012;2:115-22.

Wallace A., Romney, E.M. Roots of higher plants as a barrier to translocation of some metals to shoots of plants. In: Drucker H., Widung R.E., editors. Biological implications of metals in the environment. Proceegings $15^{\text {th }}$ Annual Hanford Life Scientific Symposium on Biological Implications of Metals in the Environment. Washington, DC: Tech Info Center, ERDA, 1977. p.370-9. 